\title{
Awareness and Satisfaction of Citizens on Green Roof Projects (GRPs) in Changwon City, South Korea
}

\author{
Jae Woo Lee ${ }^{1}$, Keun Young Huh', and Jonghoon Park ${ }^{2 *}$ \\ ${ }^{1}$ Department of Landscape Architecture, Gyeongnam National University of Science and Technology, Jinju 52725, South Korea \\ ${ }^{2}$ Department of Landscape Architecture \& Urban Planning, College of Architecture, Texas A\&M University, College Station, TX 77843-3137, US
}

\begin{abstract}
This study was designed to identify citizens' awareness and satisfaction of Green Roof Projects (GRPs) in Changwon City, South Korea. Changwon City implemented a "Green Roof Promotion Planning" project according to the city's codes and regulations from 2009 to 2011. The project introduced guidelines for ecological area rates and provided financial subsidies for the green roofing of private buildings. A citizens' survey shows that 64.8 percent of respondents have a positive awareness of GRPs and think the projects' priority should be on public buildings and commercial/office buildings. About 43.1 percent of green roof users were satisfied with green roofing in terms of housing improvement and energy saving. However, 34.6 percent of green roof users were not satisfied with regard to plant management. Educational level made a statistically meaningful difference in terms of the awareness of the project's needs and participatory spirit. Statistics of the survey showed that citizens' attitude of participation spirit was influenced by the increase in value of a building, green space expansion, and ecosystem conservation. However, their satisfaction was determined by housing improvements. The results of this survey call for a deliberate policy effort on the part of Changwon City to increase the projects'awareness, satisfaction, and participation.
\end{abstract}

Key words: factor analysis, participatory spirit, policy measure, post-occupancy evaluation, urban green space

\section{I . Introduction}

'Green' has been considered a keyword for all the governmental policy making after the recognition of environmental conservation, which has been influenced by the impacts of climate change. A lot of environmental policies have been carried out on a trial and error basis. Among these policies, green roof policy is required in many metropolitan cities which need to make themselves more environmentally friendly and develop sustainably (Carter and Fowler, 2008).

Green roof policies are efficient means of dealing with environmental problems like climate change, urban environmental and ecological degradation, and other issues (Carter and Fowler, 2008; Oberndorfer and Lundholm, 2007; Suh, 2007). For example, in the U.S., the federal government has implemented national policies which encourage green roofs to mitigate urban heat islands and storm water runoff, as well as the Urban Heat Island Pilot Project (UHIPP), which supported the ex-

Received on April 25, 2016. Revised on May 11, 2016.

Accepted on May 12, 2016.

*Corresponding author: greenwing92@gmail.com pansion of green roofs by five city governments: Baton Rouge, Chicago, Houston, Sacramento and Salt Lake City, in 1998 (Konopacki and Akbari, 2000; Wong, 1997).

In South Korea, the legal foundation for green roof expansion was laid with the establishment of the Construction Law in 1999 and the Law of Urban Parks and Greenery in 2005. In the meanwhile, Green Roof Projects (GRPs) have been carried out by metropolitan governments like Seoul City, Ulsan City, Daejeon City, Changwon City and others (Park et al., 2011).

Research on green roofs has mostly been about materials, construction methods and the effects of environmental improvement (Carter and Fowler, 2008; Chen, 2013; Henry and FrascariaLacoste, 2012; Park and Yang, 2010; Weiler and Scholz-Barth, 2009) as well as institutions (Park et al., 2011; Zhao and Kang, 2011) and rare users' behavior analysis (Jeon et al., 2011; Kim et al., 2003; Lee et al., 2005). However, there has been an insufficient number of studies about the awareness and satisfaction of users of green roofs (Kim et al., 2003), even though the studies conducted have given us more efficient information about the future direction of green roof expansion policies through assessments of conventional GRPs (Fernandez-Cañero 
et al., 2013; Jungels et al., 2013; Taib and Abdullah, 2012; Williams et al., 2010; Yuen and Nyuk Hien, 2005). Changwon City has implemented GRPs to mitigate urban heat islands, save energy for buildings, enhance urban landscapes and promote the expansion of green spaces since 2009. The regulations which provide support financial subsidies for green roof expansion in Changwon City were established in 2010, and these financial supporting policies, which are similar to ones in America and Canada, have been implemented (Park et al., 2011). The purpose of this study was to present awareness of the necessity for GRPs and promote participation in the projects as part of the enhancement of green roof provisions in urban areas. In order to achieve this, the current situation of the GRPs in Changwon City, citizens'awareness of GRPs and their effects, and users' behavior and satisfaction through post occupancy evaluation were analyzed.

\section{Methodology}

The study was performed in two parts. One part analyzed the current situation of GRPs in Changwon City while the other analyzed the results of a questionnaire on the awareness and satisfaction of the projects.

1. The current situation analysis of GRPs in Changwon City

This study analyzed the current situation of Changwon City by examining its GRPs programs, legal systems related to green roofs, surveys of the GRPs' sites and interviews. The analyzed programs and legal systems were the Green Roof Promotion Plan, the Regulation of Supporting Green Roofs and the Code of Sustainable Ecocity for Changwon City. The Green Roof Promotion Plan, the GRPs in Changwon City, was carried out during three years, from 2009 to 2011. However, the GRPs in 2009 were analyzed because the project was the only one which had been thoroughly finished among other projects. The surveys of the GRPs sites were conducted on the buildings, such as public facilities, private large buildings and single houses which had newly constructed green roofs supported by the projects or already constructed green roofs without the supports of the projects. The interviews were conducted with residents in the buildings.

\section{Questionnaire}

The questionnaire was composed of items which were designed based on socio-demographic background, preceding research on the awareness of the necessity, the effects of and civic participation in GRPs in local governments, user's behavior and post-occupancy evaluation, and interviews with the residents in study sites (Kim et al., 2003; Verderber, 1986; Whitehouse, 2001). The section of the questionnaire on the awareness of the necessity and effects was composed of five items on a 5-point Likert scale: the necessity for GRPs, the expansion of green spaces, heat islands mitigation, conservation of the ecosystem, improvement in urban landscape and improvement of buildings' values. Items related to GRPs' sites considered to be priority buildings for the support of green roof projects were written on a nominal scale and were closed-ended. The part of the questionnaire on user's behavior was composed of three items on a 5-point Likert scale: frequency, hours and purposes of use. The part on post-occupancy evaluation was composed of five items on a 5-point Likert scale: satisfaction of use, satisfaction of plant care, and environmental improvement of housing and building energy savings. The items related to causes of user's inconvenience and the other items for improvements of green roofs were written on a nominal scale and were closed-ended. The items related to decisions to participate in future GRPs were on a 5-point Likert scale.

Two hundred and fifty questionnaires were handed out to citizens who resided in the buildings supported by Changwon City GRPs for twenty days, from July 1 to 20, 2010. Following that, one hundred and ninety nine questionnaires were selected due to validity and analyzed. The collected data was given a frequency analysis, variance analysis, factor analysis and regression analysis using SPSS 12.0.0 for Windows (SPSS Inc., Chicago, Illinois, USA, 2003).

\section{Results and discussion}

\section{Current analysis of GRPs}

\section{1) Pilot projects}

Through the green roofs support program of Changwon City, financial subsidies were provided by the local government, as well as certain costs of the green roof total with its constructed 
area. This is similar to the case of Seoul. The Green Roof Promotion Plan of Changwon City was established and included financial support of about $\$ 4$ million with a total of thirty large buildings and eighty four single houses in three years. More specifically, regarding types of financial support, the entire construction cost in the case of public large buildings, fifty percent of the entire construction cost in the case of civic large buildings and ninety percent until 2009 and seventy percent since 2010 of the entire construction cost in the case of single houses were received. Green roofs were constructed on twenty single houses and two public buildings supported by GRPs in 2009.

Among public facilities supported by GRPs, there were differences according to whether the construction time of the building and green roof was coincidental or not. The intensive green roof on one public sports complex, supported by GRPs in 2009 , did not match with the building on visual quality and usage at all because the green roof was not considered when the building was being built in 1992. On the contrary, the intensive green roof on another public sports complex, also supported by GRPs in 2009, did match with the buildings' visual quality and usage well because the green roof was considered when the building was being built.

Among civic large buildings supported by GRPs, there were differences according to whether the buildings were for residential use or commercial use. A residential building (CBuilding) satisfied users because it had an intensive gardenlike green roof which was as big as a small park in its scale and included water spaces and resting and strolling places. However, giant markets and department stores, although they were supported in the same way, already got rid of green roofs to substitute them for parking spaces or prevent users from entering green roofs for safety reasons.

Changwon City's approach to conducting GRPs on single houses was new; other cities' GRPs mainly focused on public facilities and civic large buildings. The construction of single houses started at a time when public facilities and civic large buildings were common in Changwon City. Thirty four single houses near C-Building were selected as green roofs support sites for the purpose of improving undesirable cityscapes. After removing useless rooftop water tanks and doing waterproof work, thirty four green roofs were constructed on each single house with an averaged area of $100 \mathrm{~m}^{2}$ which included mostly herbaceous flowers, several shrubs, resting places like low wooden benches, and couches in view of an allowable load of the rooftop. Although they had high construction costs, the roof railing and rooftop-access stairs were considered not safe and in need of more safety measures. In the meantime, citizens who participated in the projects were generally satisfied but worried about water leakage from green roofs during the summertime rainy season.

2) Legal system

Green roofs are mainly supported by the Building Act. In Changwon City, the Rules of the Green roofs Support in Changwon City was enacted on July, 2010 based on the Building Regulation in Changwon City. This regulation includes details for green roofs supports like that of Uiwang City. In Article 5, there is a qualification for candidates of green roofs support, which include buildings for citizens' frequent uses and public concerns like hospitals and welfare facilities, buildings for education use and field work like nursery facilities and kindergartens, buildings for free access and carrying lots of citizens as well as their various activities like commercial and business use buildings, and other buildings which have passed structural safety tests and have been ordered to have a new green roof by the mayor. Incidentally, there are no details provided about financial subsidies like those in higher national law and other local governments. If local governments succeed in invigorating green roofs, related policies should be diversified in terms of financial subsidies and supported by various agents similar to the way that American local governments does (Park et al., 2011). If this were the case, the green roofs supporting policies could lighten the financial burden of local governments.

Moreover, in Changwon City, ecological guidelines are applied to public facilities and all buildings in the administrative area by Item 2 of Clause 1 of Article 2 of Building law to enable Changwon City to develop into an environmentally sound and sustainable ecocity. There are ecological guidelines to construct green roofs on public facilities in Clause 6, ecological guidelines for public facilities, of Article 8 of Rules of Sustainable Ecocity of Changwon City and on buildings in Clause 7 of Article 8 of same rule, respectively. These two clauses state that green roofs can serve as functions in habitats like those of 
local governments in England and Swiss (Park et al., 2011). Also, there is a guideline of the Biotop Area Ratio, an urban environmental indicator (Lakes and Kim, 2012) which provides guidelines to calculate the quantity of green roofs and other green spaces in urban areas in Clause 9 of Article 8 of Rules of Sustainable Ecocity of Changwon City. According to this rule, public facilities must basically apply the guidelines of the Biotop Area Ratio and civic buildings can be provided financial subsidies to encourage the provision of green roofs.

\section{Awareness and satisfaction of GRPs}

\section{1) Socio-demographic background}

An examination of the socio-demographic background of respondents who lived in GRPs areas shows that men comprised 61.1 percent and women 38.9 percent in terms of gender, and 42.9 percent were in their $50 \mathrm{~s}, 25.3$ percent in their $40 \mathrm{~s}$ and 17.7 percent in their $30 \mathrm{~s}$ with regard to age (Table 1). In terms of education, 44.3 percent had high school diplomas and 41.7 percent had college graduates. Related to housing, 56.1 percent and 35.7 percent of residents lived in apartments and single houses, respectively. Finally, as far as housing ownership, 77.7

Table 1. Socio-demographic background.

\begin{tabular}{|c|c|c|c|}
\hline & Variable & Frequency & Valid percent (\%) \\
\hline \multirow{2}{*}{ Gender } & Female & 121 & 61.1 \\
\hline & Male & 77 & 38.9 \\
\hline \multirow{5}{*}{ Age (year) } & under 30 & 18 & 9.1 \\
\hline & $30 \mathrm{~s}$ & 35 & 17.7 \\
\hline & $40 \mathrm{~s}$ & 50 & 25.3 \\
\hline & $50 \mathrm{~s}$ & 85 & 42.9 \\
\hline & 60 s and over & 10 & 5.1 \\
\hline \multirow{4}{*}{ Education } & Middle school & 16 & 8.3 \\
\hline & High school & 85 & 44.3 \\
\hline & College/university & 80 & 41.7 \\
\hline & Graduate school & 11 & 5.7 \\
\hline \multirow{4}{*}{$\begin{array}{l}\text { Housing } \\
\text { type }\end{array}$} & Apartment & 110 & 56.1 \\
\hline & Single family house & 70 & 35.7 \\
\hline & Multiplex house & 8 & 4.1 \\
\hline & Other & 8 & 4.1 \\
\hline \multirow{2}{*}{ Ownership } & Own & 153 & 77.7 \\
\hline & Rent & 44 & 22.3 \\
\hline
\end{tabular}

percent lived in their own housing and 22.3 percent in rental housing.

2) Awareness of the necessity and effects of GRPs

Respondents who had a positive awareness of the necessity for GRPs were 64.8 percent while 19.6 percent were negative in their awareness (Table 2). 59.9 percent of respondents chose public facilities as priority buildings to be supported for green roofs, 20.3 percent chose commercial and business use buildings and 13.2 percent chose housing. These results show citizens have a positive awareness of the necessity for GRPs and recognize public facilities and commercial use and business use buildings as proper sites for GRPs.

As for the effects of GRPs, 65.3 percent of respondents were positive about 'green spaces expansion' while 21.6 percent were negative (Table 3). 71.2 percent were positive about 'heat island mitigation' while 17.2 percent were negative. About 'conservation of the ecosystem,' 48.7 percent were positive and 30.5 percent negative. Regarding 'improvement of aesthetic quality,' 72.3 percent were positive and 17.6 percent negative. 50.4 percent were positive and 26.6 percent negative about 'improvement of buildings' value.' These results show that GRPs can be effective for 'green spaces expansion,' 'heat island mitigation' and 'improvement of cityscapes' in urban areas. However, although green roofs have other effects to conserve the ecosystem (Brenneisen, 2006; Francis and Lorimer, 2011; Miller, 2005; Wolf and Lundholm, 2008) and improve buildings' values (Bianchini and Hewage, 2012; Clark et al.,

Table 2. Awareness of the necessity for GRPs and preferred buildings for green roof in Changwon City.

\begin{tabular}{llcc}
\hline & Variable & Frequency & Valid percent (\%) \\
\hline & Definitely not & 15 & 7.5 \\
& Probably not & 24 & 12.1 \\
Necessity & Uncertain & 31 & 15.6 \\
for GRPs & Probably yes & 95 & 47.7 \\
& Definitely yes & 34 & 17.1 \\
\hline & Public & 118 & 59.9 \\
Preferred & Commercial/office & 40 & 20.3 \\
buildings & Residential & 26 & 13.2 \\
for GRPs & Other & 13 & 6.6 \\
\hline
\end{tabular}


Table 3. Awareness of the effects on green roof in Changwon City.

\begin{tabular}{|c|c|c|c|}
\hline \multicolumn{2}{|c|}{ Variable } & Frequency & Valid percent (\%) \\
\hline \multirow{5}{*}{$\begin{array}{l}\text { Widening of } \\
\text { green space }\end{array}$} & Definitely not & 18 & 9.0 \\
\hline & Probably not & 25 & 12.6 \\
\hline & Uncertain & 26 & 13.1 \\
\hline & Probably yes & 75 & 37.7 \\
\hline & Definitely yes & 55 & 27.6 \\
\hline \multirow{5}{*}{$\begin{array}{l}\text { Mitigation of } \\
\text { heat island }\end{array}$} & Definitely not & 12 & 6.1 \\
\hline & Probably not & 22 & 11.1 \\
\hline & Uncertain & 23 & 11.6 \\
\hline & Probably yes & 77 & 38.9 \\
\hline & Definitely yes & 64 & 32.3 \\
\hline \multirow{5}{*}{$\begin{array}{l}\text { Conservation } \\
\text { of ecosystem }\end{array}$} & Definitely not & 21 & 10.7 \\
\hline & Probably not & 39 & 19.8 \\
\hline & Uncertain & 41 & 20.8 \\
\hline & Probably yes & 66 & 33.5 \\
\hline & Definitely yes & 30 & 15.2 \\
\hline \multirow{5}{*}{$\begin{array}{l}\text { Improvements } \\
\text { of aesthetic } \\
\text { qualities }\end{array}$} & Definitely not & 10 & 5.0 \\
\hline & Probably not & 25 & 12.6 \\
\hline & Uncertain & 20 & 10.1 \\
\hline & Probably yes & 86 & 43.2 \\
\hline & Definitely yes & 58 & 29.1 \\
\hline \multirow{5}{*}{$\begin{array}{l}\text { Improvement of } \\
\text { buildings' value }\end{array}$} & Definitely not & 13 & 6.5 \\
\hline & Probably not & 40 & 20.1 \\
\hline & Uncertain & 37 & 18.6 \\
\hline & Probably yes & 79 & 39.7 \\
\hline & Definitely yes & 30 & 15.1 \\
\hline
\end{tabular}

2008; Johnston and Newton, 2004; Santamouris, 2014), respondents did not recognize this as much.

3) User's behavior and Post-occupancy evaluation

Regarding 'frequency of green roofs use,' 31.8 percent of respondents visited green roofs more than one time on weekdays or weekends and 68.2 percent less than one time (Table 4). About 'time of green roofs use,' 38.3 percent, 27.9 percent, 24.0 percent and 9.7 percent of respondents chose noon, evening, afternoon and morning, respectively. In terms of 'purpose of green roofs use,' 62.6 percent chose relaxation, 19.9 percent management, 5.3 percent telephone conversation and 4.1 percent for smoking. These results show that green roofs users visit green roofs less than once a week, in the afternoon and to
Table 4. User's behaviors on green roofs in Changwon City.

\begin{tabular}{|c|c|c|c|}
\hline & Variable & Frequency & Valid percent $(\%)$ \\
\hline \multirow{5}{*}{$\begin{array}{l}\text { Frequency } \\
\text { of use }\end{array}$} & Everyday & 12 & 6.1 \\
\hline & 3-5 times/week & 9 & 4.5 \\
\hline & 1-2 times/week & 29 & 14.6 \\
\hline & Weekends & 13 & 6.6 \\
\hline & less than the others & 135 & 68.2 \\
\hline \multirow{4}{*}{$\begin{array}{l}\text { Time } \\
\text { of use }\end{array}$} & Forenoon & 15 & 9.7 \\
\hline & Noon & 59 & 38.3 \\
\hline & Afternoon & 37 & 24.0 \\
\hline & Evening & 43 & 27.9 \\
\hline \multirow{6}{*}{$\begin{array}{l}\text { Purpose } \\
\text { of use }\end{array}$} & Relaxation & 107 & 62.6 \\
\hline & Smoking & 7 & 4.1 \\
\hline & Telephone conversation & 9 & 5.3 \\
\hline & Having a meal & 0 & 0.0 \\
\hline & Maintenance & 34 & 19.9 \\
\hline & Others & 14 & 8.2 \\
\hline
\end{tabular}

Table 5. Post occupancy evaluation on green roof in Changwon City.

\begin{tabular}{|c|c|c|c|}
\hline \multicolumn{2}{|c|}{ Variable } & Frequency & Valid percent (\%) \\
\hline \multirow{5}{*}{$\begin{array}{l}\text { Satisfaction } \\
\text { of use }\end{array}$} & Very unsatisfied & 11 & 6.1 \\
\hline & Unsatisfied & 27 & 14.9 \\
\hline & Ordinary & 65 & 35.9 \\
\hline & Satisfied & 52 & 28.7 \\
\hline & Very satisfied & 26 & 14.4 \\
\hline \multirow{5}{*}{$\begin{array}{l}\text { Satisfaction } \\
\text { of plant } \\
\text { maintenances }\end{array}$} & Very unsatisfied & 18 & 9.7 \\
\hline & Unsatisfied & 46 & 24.9 \\
\hline & Ordinary & 73 & 39.5 \\
\hline & Satisfied & 40 & 21.6 \\
\hline & Very satisfied & 8 & 4.3 \\
\hline \multirow{5}{*}{$\begin{array}{l}\text { Improvement } \\
\text { of residential } \\
\text { environment }\end{array}$} & Definitely not & 12 & 6.3 \\
\hline & Probably not & 29 & 15.3 \\
\hline & Uncertain & 62 & 32.8 \\
\hline & Probably yes & 74 & 39.2 \\
\hline & Definitely yes & 12 & 6.3 \\
\hline \multirow{5}{*}{$\begin{array}{l}\text { Saving of air } \\
\text { conditioning } \\
\text { and heating cost }\end{array}$} & Definitely not & 12 & 6.5 \\
\hline & Probably not & 33 & 17.7 \\
\hline & Uncertain & 64 & 34.4 \\
\hline & Probably yes & 63 & 33.9 \\
\hline & Definitely yes & 14 & 7.5 \\
\hline
\end{tabular}

rest.

Regarding 'satisfaction of use,' 14.4 percent and 28.7 percent of respondents selected 'very satisfied' and 'satisfied,' res- 
pectively, while 56.9 percent chose rest items meaning ordinary (35.9 percent) or unsatisfied (21.0 percent) (Table 5). About 'satisfaction of plant maintenances,' 4.3 percent and 21.6 percent of respondents selected 'very satisfied' and 'satisfied,' respectively, while 39.5 percent chose 'ordinary' and 34.6 percent 'unsatisfied and very unsatisfied.' As for 'improvement of residential environment,' 45.5 percent of respondents were positive while 21.6 percent negative. As for 'saving of air conditioning and heating cost,' 41.4 percent of respondents were positive while 24.2 percent negative. These results show that 43.1 percent of respondents were satisfied with using green roofs and shared similarity with the tendency of 'improvement of residential environment' and 'saving of air conditioning and heating costs.' However, 34.6 percent of respondents were not satisfied with plant maintenances while 25.9 percent were satisfied with them.

'Discomfort of use' included six items: 'plant maintenance,' 'rooftop defects,' 'access,' 'safety,' 'workability' and 'others.' 37.3 percent of respondents chose 'rooftop defects,' while 28.8 percent and 19.4 percent 'access' and 'plant maintenance,' respectively (Table 6). 'Proposal of improvement' included five items, 'diversity of plants,' 'increase of financial subsidies,' 'free from rooftop defects such as water leakage,' 'reduction of administrative process' and 'others.' 61.8 percent of respondents chose 'free from rooftop defects,' while 19.4 percent 'increase of financial subsidies' (Table 6). These results show that to invigorate GRPs, measures like safety assurance, improvement of accessibility and an increase in financial subsidies are necessary in advance, and 'plant maintenance,' 'diversity of plants' and 'reduction of administrative process' afterwards.

4) Willingness to participate in GRPs

When the item, "Would you like to recommend neighbors (building-owners) to participate on GRPs?", was asked on a 5-point Likert scale, 56.9 percent of respondents were positive while 14.8 percent negative (Table 7). This result shows that most citizens have a positive awareness and high willingness to participate in GRPs in Changwon City.

Table 6. Discomfort of use and proposal of improvement on green roof in Changwon City.

\begin{tabular}{|c|c|c|c|}
\hline & Variable & Frequency & Valid percent $(\%)$ \\
\hline \multirow{6}{*}{ Discomfort of use } & Plant maintenance & 33 & 17.1 \\
\hline & Rooftop defects (water leakage etc.) & 72 & 37.3 \\
\hline & Access (stairs etc.) & 46 & 23.8 \\
\hline & Safety (fence etc.) & 14 & 7.3 \\
\hline & Workability (to install outdoor fan etc.) & 23 & 11.9 \\
\hline & Others & 5 & 2.6 \\
\hline \multirow{5}{*}{ Proposal of improvement } & Diversity of plants & 12 & 6.3 \\
\hline & Increase of financial subsidies & 37 & 19.4 \\
\hline & Free from rooftop defects (water leakage etc.) & 118 & 61.8 \\
\hline & Reduction of administrative process & 16 & 8.4 \\
\hline & Others & 8 & 4.2 \\
\hline
\end{tabular}

Table 7. Willingness to participate in GRPs in Changwon City.

\begin{tabular}{|c|c|c|c|}
\hline Variable & & Frequency & Valid percent $(\%)$ \\
\hline \multirow{5}{*}{ Willing to recommend the GRPs to others as well as you } & Definitely not & 10 & 5.1 \\
\hline & Probably not & 19 & 9.7 \\
\hline & Uncertain & 55 & 28.2 \\
\hline & Probably yes & 80 & 41.0 \\
\hline & Definitely yes & 31 & 15.9 \\
\hline
\end{tabular}


5) Improvement of awareness of GRPs' necessities and participation in GRPs

To invigorate GRPs in Changwon City, an improvement of awareness of GRPs' necessities and participation in GRPsis needed. From the results shown previously, it can be assumed that education and knowledge of the past can impact awareness and participation. In addition, from this assumption, it was deduced that educational standards, an awareness of GRPs' effects, user's behavior and post occupancy evaluation are factors which can be expected to improve GRPs in the future.

From the cross-tabulations of respondents' education and necessity for GRPs, Pearson's chi-square value was 43.766 with asymptotic significance 0.000 and 12 degree of freedom. This means that there is correlation between education and necessity for GRPs; more specifically, the higher the education, the more positive awareness and the necessity for GRPs was (Table 8).

From the cross-tabulations of respondents' education and willingness to participate in GRPs, Pearson's chi-square value was 49.891 with asymptotic significance 0.000 and 12 degree of freedom. This indicates that there is correlation between education and willingness to participate in GRPs; more specifically, the higher the education, the more positive awareness and the willingness of participation on GRPs was (Table 9).

Before regression analysis, selecting influential variables for improvement of the awareness of GRPs'necessities and willingness to participate in GRPs and making a regression model, a factor analysis was carried out about related variables within awareness of GRPs'effects, frequency of use and post occupancy evaluation through KMO (Kaser-Meyer-Olkin) test and PCA (principle component analysis) with varimax rotation. The $\mathrm{KMO}$ value $=0.889$ was considerably large and indicated that the variables for factor analysis were proper. Moreover, whether common factors existed was verified by the value of the Bartlett's test $=1121.576$ (significance $=0.000$ ), which implies the adequacy of the factor analysis model. Factor 1 can be decided as 'awareness of the effects of GRPs' because 'mitigation of heat island,' 'widening of green space,' 'conservation of ecosystem' and 'improvement of aesthetic qualities' belong to

Table 8. Cross-tabulation of awareness of the necessity for GRPs and education of users.

\begin{tabular}{|c|c|c|c|c|c|c|}
\hline \multirow{2}{*}{\multicolumn{2}{|c|}{ Variable }} & \multicolumn{4}{|c|}{ Education } & \multirow{2}{*}{ Tota } \\
\hline & & M & $\mathrm{H}$ & $\mathrm{C} / \mathrm{U}$ & $\mathrm{G}$ & \\
\hline \multirow{5}{*}{$\begin{array}{l}\text { Awareness on the necessity } \\
\text { for GRPs }\end{array}$} & Definitely not & 2 & 8 & 3 & 0 & 13 \\
\hline & Probably not & 8 & 12 & 3 & 1 & 24 \\
\hline & Uncertain & 0 & 15 & 14 & 0 & 29 \\
\hline & Probably yes & 5 & 42 & 41 & 5 & 93 \\
\hline & Definitely yes & 1 & 8 & 19 & 5 & 33 \\
\hline \multicolumn{2}{|l|}{ Total } & 16 & 85 & 80 & 11 & 192 \\
\hline
\end{tabular}

M: middle school; H: high school; C/U: college or university; G: graduate school.

Table 9. Cross-tabulation of willingness to participate in GRPs and education of users.

\begin{tabular}{|c|c|c|c|c|c|c|}
\hline \multirow{2}{*}{ Variable } & & \multicolumn{4}{|c|}{ Education } & \multirow{2}{*}{ Total } \\
\hline & & M & $\mathrm{H}$ & $\mathrm{C} / \mathrm{U}$ & G & \\
\hline \multirow{5}{*}{ Willing to recommend the GRPs to others as well as you } & Definitely not & 5 & 4 & 0 & 0 & 9 \\
\hline & Probably not & 3 & 12 & 3 & 1 & 19 \\
\hline & Uncertain & 2 & 24 & 26 & 0 & 52 \\
\hline & Probably yes & 3 & 36 & 36 & 5 & 80 \\
\hline & Definitely yes & 3 & 8 & 14 & 5 & 30 \\
\hline Total & & 16 & 84 & 79 & 11 & 190 \\
\hline
\end{tabular}

M: middle school; H: high school; C/U: college or university; G: graduate school. 
'awareness of GRPs' effects' (Table 10). Factor 2 can be determined as 'satisfaction of GRPs' because 'saving of air conditioning and heating costs,' 'frequency of use,' 'satisfaction of use,' 'satisfaction of plant maintenance' and 'improvement of residential environment' belonged to 'satisfaction of GRPs' (Table 10).

The regression model: equation 1 (Eq. 1), composed of 'awareness of the necessity for GRPs (Y1)' for a dependent variable and 'awareness of the effects of GRPs (F1, factor 1)'and 'satisfaction of GRPs (F2, factor 2)' for independent variables, was established by a regression analysis using stepwise

Table 10. Rotated component matrix of variables related to awareness and satisfaction on green roof in Changwon City.

\begin{tabular}{lcc}
\hline \multirow{2}{*}{ Variable } & \multicolumn{2}{c}{ Component } \\
\cline { 2 - 3 } & Factor 1 & Factor 2 \\
\hline Mitigation of heat island & 0.854 & 0.270 \\
Widening of green space & 0.844 & 0.224 \\
Conservation of ecosystem & 0.832 & 0.128 \\
Improvement of aesthetic qualities & 0.823 & 0.241 \\
Improvement of buildings' value & 0.751 & 0.342 \\
Saving of air conditioning and heating costs & 0.542 & 0.528 \\
Frequency of use & -0.044 & 0.793 \\
Satisfaction of use & 0.480 & 0.695 \\
Satisfaction of plant maintenance & 0.389 & 0.632 \\
Improvement of residential environment & 0.566 & 0.617 \\
\hline
\end{tabular}

Extraction method: Principal component analysis. Rotation method: Varimax with Kaiser normalization. procedures $(\mathrm{R} 2=0.554, \mathrm{~F}=105.438, \mathrm{P}<0.01)$. The regression model: equation 2 (Eq. 2), composed of 'willingness of participation on GRPs (Y2)' for a dependent variable and 'awareness of the effects of GRPs (F1, factor 1)' and 'satisfaction of GRPs (F2, factor 2)' for independent variables, was established by a regression analysis $(\mathrm{R} 2=0.602, \mathrm{~F}=126.350, \mathrm{P}<0.01)$.

$$
\begin{aligned}
& \mathrm{Y} 1=3.555+0.781 \times \mathrm{F} 1+0.328 \times \mathrm{F} 2 \ldots \ldots . . \text { Eq. } 1 \\
& \mathrm{Y} 2=3.555+0.693 \times \mathrm{F} 1+0.396 \times \mathrm{F} 2 \ldots \ldots . \text { Eq. } 2
\end{aligned}
$$

The result shows that 'awareness of the effects of GRPs (F1)' and 'satisfaction of GRPs (F2)'are very significant factors for 'awareness of the necessity for GRPs (Y1)' and 'willingness of participation on GRPs (Y2)' while F1 shows a stronger impact on the regression model than F2 does.

Finally, to select more specific variables to improve awareness of the necessity for GRPs and also the willingness to participate in GRPs, two other regression models were established respetively. One model consisted of independent variables which belonged to 'awareness of the effects of GRPs' and 'satisfaction of GRPs' and 'awareness of the necessity for GRPs' for a dependent variable. The other model had 'willingness of participation on GRPs'as a dependent variable and the same independent variables on the previous model (Table 11). The variables which gave a very significant impact on 'awareness of the necessity for GRPs' were 'widening green spaces' and 'improvement of aesthetic qualities' from the variables in

\begin{tabular}{|c|c|c|c|c|c|c|c|c|}
\hline \multirow{2}{*}{$\begin{array}{l}\text { Dependent } \\
\text { variable }\end{array}$} & \multirow[t]{2}{*}{ Independent variables } & \multicolumn{2}{|c|}{$\begin{array}{c}\text { Unstandardized } \\
\text { coefficients }\end{array}$} & \multirow{2}{*}{$\begin{array}{c}\begin{array}{c}\text { Standardized } \\
\text { coefficients }\end{array} \\
\text { Beta }\end{array}$} & \multirow[t]{2}{*}{ T value } & \multirow[t]{2}{*}{ Sig.T } & \multirow[t]{2}{*}{$\mathrm{R}^{2}$} & \multirow[t]{2}{*}{ F value } \\
\hline & & $\mathrm{B}$ & Std. error & & & & & \\
\hline \multirow{2}{*}{$\begin{array}{l}\text { Awareness of } \\
\text { the necessity } \\
\text { for GRPs }\end{array}$} & Widening of green space & 0.491 & 0.063 & 0.542 & 7.824 & 0.000 & \multirow{2}{*}{$0.601^{* *}$} & \multirow{2}{*}{85.003} \\
\hline & Improvement of aesthetic qualities & 0.176 & 0.068 & 0.179 & 2.565 & 0.011 & & \\
\hline \multirow{5}{*}{$\begin{array}{l}\text { Willingness to } \\
\text { participate in } \\
\text { GRPs }\end{array}$} & (constant) & 0.734 & 0.187 & & 3.924 & 0.000 & \multirow{5}{*}{$0.604^{* *}$} & \multirow{5}{*}{62.787} \\
\hline & Improvement of buildings' values & 0.217 & 0.064 & 0.246 & 3.408 & 0.001 & & \\
\hline & Improvement of residential environment & 0.303 & 0.068 & 0.294 & 4.447 & 0.000 & & \\
\hline & Widening of green space & 0.182 & 0.061 & 0.221 & 2.989 & 0.003 & & \\
\hline & Conservation of the ecosystem & 0.134 & 0.061 & 0.159 & 2.217 & 0.028 & & \\
\hline
\end{tabular}

Table 11. Regression models of awareness of the necessity and willingness to participate in GRPs with awareness of the effects and satisfaction.

\footnotetext{
${ }^{* *}$ Significance value $=0.000$
} 
'awareness of the effects of GRPs' and 'improvement of residential environment' from the variables in 'satisfaction of GRPs.' Among these three variables, 'widening green spaces' was the strongest. The variables which had a very significant impact on 'willingness of participation on GRPs' were 'improvement of buildings' values,' 'widening of green space' and 'conservation of the ecosystem' from variables of 'awareness of the effects of GRPs' and 'improvement of residential environments' from the variables in 'satisfaction of GRPs.' Among these four variables, 'improvement of buildings' values' was the strongest.

\section{Conclusion}

This study was aimed at invigorating green roof projects in urban and carried out in the following manner: The study analyzed the current situation of GRPs of Changwon City, citizens' awareness of the necessity and the effects and satisfaction of GRPs through user's behavior, post occupancy evaluation and policy measures to enhance GRPs in the future.

GRPs of Changwon City supports selected candidates for a certain amount, which is a part of total green roof area and is raised by the local government. To extend green roofs for public facilities, the green roof guidelines of the Biotop Area Ratio and for civic buildings should be followed. In addition, there are financial subsidies to encourage green roofs.

Citizens generally have a positive awareness of the necessity for GRPs and think the projects' priority should be public facilities and buildings for commercial and business use. They also think GRPs are generally effective for 'improvement of aesthetic qualities,' 'mitigation of heat island' and 'widening of green space.' On the other hand, they think GRPs are not effective for 'conservation of ecosystem' and 'improvement of buildings' values.' Most of the respondents use green roofs about once a week, in the afternoon and for relaxation. The result that 43.1 percent of respondents were satisfied with the use of green roofs is similar in percent value with 'improvement of residential environment' and 'saving of air conditioning and heating costs.' However, respondents had a low degree of awareness of 'satisfaction of plant maintenance.' To invigorate GRPs, the result showed that 'free from rooftop defects,' 'increase of financial subsidies' and 'safety to use stairs and fences' are necessary in advance; following that are plant management, plants'diversity and simplifying administrative procedure. Besides, most citizens are positively aware of GRPs and show a higher willingness to participate in GRPs. Related to that, the higher the education, the more positive awareness of the necessity for GRPs and willingness to participate in GRPs was.

Awareness of the effects and satisfaction of GRPs are very significant variables to improve awareness of the necessity and willingness to participate in GRPs. Awareness of the effects of GRPs shows a stronger impact than satisfaction of GRPs on awareness of the necessity and willingness to participate in GRPs. More specifically, the strongly affecting variables on awareness of the necessity for GRPs were expanding green spaces and improving aesthetic quality in awareness of the effects on GRPs as well as improving residential environments in satisfaction of GRPs. Among these variables, being aware of expanding green roofs has a strong impact. The strongly affecting variables on willingness to participate in GRPs were improving buildings'values, expanding green spaces and conserving the ecosystem in awareness of the effects on GRPs, and improving residential environments in satisfaction of GRPs. Among these variables, being aware of improving buildings' value had a strong impact. In the future, countermeasures that increase factors in awareness of GRPs' effects and satisfaction will be needed.

\section{References}

Bianchini, F. and K. Hewage. 2012. Probabilistic social cost-benefit analysis for green roofs: a life cycle approach. Build. Environ. $58: 152-162$

Brenneisen, S. 2006. Space for urban wildlife: designing green roofs as habitats in Switzerland. Urban Habitats 4(1):27-36.

Carter, T. and L. Fowler. 2008. Establishing green roof infrastructure through environmental policy instruments. Environ. Manage. 42(1):151-164.

Chen, C.F. 2013. Performance evaluation and development strategies for green roofs in Taiwan: a review. Ecol. Eng. 52:51-58.

Clark, C., P. Adriaens, and F.B. Talbot. 2008. Green roof valuation: a probabilistic economic analysis of environmental benefits. Environ. Sci. Technol. 42:2155-2161.

Dvorak, B. and A. Volder. 2010. Green roof vegetation for north american ecoregions: a literature review. Landsc. Urban Plan. 96(4):197-213. 
Fernandez-Cañero, R., T. Emilsson, C. Fernandez-Barba, and M.Á.H. Machuca. 2013. Green roof systems: a study of public attitudes and preferences in southern Spain. J. Environ. Manage. 128:106115.

Francis, R.A. and J. Lorimer. 2011. Urban reconciliation ecology: the potential of living roofs and walls. J. Environ. Manage. 92(6): 1429-1437.

Henry, A. and N. Frascaria-Lacoste. 2012. The green roof dilemma discussion of Francis and Lorimer (2011). J. Environ. Manage. 104:91-92.

Jeon, E.J., S. Chung, and T. Lee. 2011. Revitalization plan of green roof through analysis of demand on. J. Kor. Soc. Environ. Adm. 17(2):131-140.

Johnston, J. and J. Newton. 1993. Building green: a guide to using plants on roofs, walls and pavements, Ecology Unit, London, UK.

Jungels, J., D.A. Rakow, S.B. Allred, and S.M. Skelly. 2013. Attitudes and aesthetic reactions toward green roofs in the Northeastern United States. Landsc. Urban Plan. 117:13-21.

Kim, I., K.Y. Huh, A.H. Choi, and Y.I. Kim. 2003. The Postoccupancy evaluation of roof garden at hospital: a case study of Asan medical center - (in Korean). J. Korean Inst. Landsc. Archit. 31(5):58-72.

Konopacki, S. and H. Akbari. 2000. Energy savings calculations for heat island reduction strategies in Baton Rouge, Sacramento and Salt Lake City. Lawrence Berkeley Natl. Lab.

Lakes, T. and H.O. Kim. 2012. The urban environmental indicator "Biotope Area Ratio": an enhanced approach to assess and manage the urban ecosystem services using high resolution remote-sensing. Ecol. Indic. 13(1):93-103.

Lee, D.K., S.W. Yoon, S.H. Oh, and S.W. Jang. 2005. The evaluation of present condition and visitors satisfaction of rooftop greening (in Korean). J. Korea Soc. Environ. Restor. Technol. 8(6):45-58.

Miller, J.R. 2005. Biodiversity conservation and the extinction of experience. Trends Ecol. Evol. 20(8):430-434.

Oberndorfer, E. and J. Lundholm. 2007. Green roofs as urban ecosystems: ecological structures, functions, and services. Biosci. 57(10):823-833.

Park, J., K.Y. Huh, H. Shin, N. Park, and K. Choi. 2011. Analysis of domestic and foreign legal cases and legal improvements related to green roof in Korea (in Korean). J. Korean Soc. People Plants
Environ. 14(5):307-314.

Park, J., S. Kim, and B. Yang. 2010. National and international research trend of green roofs' effects and construction methods (in Korean). J. Korean Soc. People Plants Environ. 13(6):87-99.

Santamouris, M., C. Pavlou, P. Doukas, G. Mihalakakou, A. Synnefa, A. Hatzibiros, and P. Patargias. 2007. Investigating and analysing the energy and environmental performance of an experimental green roof system installed in a nursery school building in Athens, Greece. Energy 32(9):1781-1788.

Santamouris, M. 2014. Cooling the cities - a review of reflective and green roof mitigation technologies to fight heat island and improve comfort in urban environments. Sol. Energy 103:682-703.

Suh, E.C. 2007. A study on the mitigation policies for urban heat island (in Korean). J. Korean Inst. Ecol. Archit. Environ. 7(2):17-24.

Taib, N. and A. Abdullah. 2012. Study of landscape gardens: expectations and users' perceptions of a high-rise office building. Procedia Soc. Behav. Sci. 50:633-642.

Verderber, S. 1986. Dimensions of person-window transactions in the hospital environment. Environ. Behav. 18(4):450-466.

Weiler, S.K. and K. Scholz-Barth. 2009. Green roof systems: a guide to the planning, design, and construction of landscapes over structure. John Wiley \& Sons, N.J., USA.

Whitehouse, S. 2001. Evaluating a children's hospital garden environment: utilization and consumer satisfaction. J. Environ. Psychol. 21(3):301-314.

Williams, N.S., J.P. Rayner, and K.J. Raynor. 2010. Green roofs for a wide brown land: opportunities and barriers for rooftop greening in Australia. Urban For. Urban Green. 9(3):245-251.

Wolf, D. and J. Lundholm. 2008. Water uptake in green roof microcosms: effects of plant species and water availability. Ecol. Eng. 33(2): 179-186.

Wong, E. 1997. The U.S. environmental protection agency's Heat Island Reduction Initiative (HIRI): status and future directions. U.S. Environ. Prot. Agency.

Yuen, B. and W. Nyuk Hien. 2005. Resident perceptions and expectations of rooftop gardens in Singapore. Landsc. Urban Plan. 73(4):263-276.

Zhao, H.X. and T.H. Kang. 2011. A Comparative study on the legal system of building a rooftop gardening between Korea and China. J. Korean Inst. Landsc. Archit. 39(4):11-17. 